\title{
Neosilba Perezi (Romero \& Ruppel, 1973) (Diptera: Lonchaeidae) Damage Simulation on the Production of Stem Cuttings and the Productive Aspects of Cassava
}

\author{
Humberto Godoy Androcioli ${ }^{1}$, Adriano Thibes Hoshino ${ }^{2}$, Juliana Sawada Buratto ${ }^{1}$, João Henrique Caviglione ${ }^{1}$, \\ Rodolfo Bianco ${ }^{1}$, Luciano Mendes de Oliveira ${ }^{2}$, Adevanir Martins dos Santos ${ }^{4}$, Marcelo Augusto Pastório ${ }^{3}$ \\ \& Wilmar Ferreira Lima ${ }^{1}$ \\ ${ }^{1}$ Instituto Agronômico do Paraná, Londrina, Brazil \\ ${ }^{2}$ Universidade Estadual de Londrina, Londrina, Brazil \\ ${ }^{3}$ Universidade Estadual do Oeste do Paraná, Marechal Cândido Rondon, Brazil \\ ${ }^{4}$ Universidade Pitágoras Londrina, Londrina, Brazil \\ Correspondence: Humberto Godoy Androcioli, Instituto Agronômico do Paraná (IAPAR), Londrina, PR, Brazil. \\ Tel: 55-43-3376-2298. E-mail: handrocioli@iapar.br
}

Received: August 13, 2019

doi:10.5539/jas.v11n18p166

\author{
Accepted: October 5, 2019 \\ Online Published: November 15, 2019 \\ URL: https://doi.org/10.5539/jas.v11n18p166
}

\begin{abstract}
The loss caused by the shoot-fly (Neosilba perezi) was simulated through the elimination of the cassava's terminal buds, with the objective to quantify this effect towards the roots productivity, flour production and propagative material production (stem cuts). The experimental design was random blocks, with three repetitions, in a factorial scheme with an additional treatment $(10 \times 4+1)$. Ten damage levels $(10,20,30,40,50,60,70,80$, 90 and $100 \%)$ were studied, including a witness treatment $(0 \%)$. The cassavas were treated during each of the four seasons of the year. The studied variables were: root productivity $\left(\mathrm{tha}^{-1}\right)$, flour production $\left(\mathrm{t} \mathrm{ha} \mathrm{s}^{-1}\right)$ and number of stem cuttings with a diameter greater than 20 and $25 \mathrm{~mm}$. The induced damage in the cassava's meristem did not significantly affect the root, nor the flour production. However, the stem cuttings production demonstrated a linear decrease in relation to the apical meristem damage level.
\end{abstract}

Keywords: Manihot esculenta, Neosilba perezi, productivity, propagative material

\section{Introduction}

The cassava (Manihot esculenta Crantz) stands out for its versatility in human and animal feeding, it is of great importance towards food security and the sustainability of production systems in tropical regions of Africa, Asia and Latin America [Food and Agriculture Organization of the United Nations (FAO), 2019a]. The cassava's cultivation adapts to different soil and climatic conditions (Aidar et al., 2015), and can be cultivated as an annual or biennial crop (El-Sharkawy, 2003). In the year of 2017, Brazil was the fifth largest producer of cassava in the world, behind Nigeria, the Democratic Republic of Congo, Thailand and Indonesia (FAO, 2018b). In Brazil, the crop is responsible for the subsistence and revenue income of many small farmers, as well as large crop productions to supply the raw materials for an industrial complex of flour, starch and products for the chemical, textile and cosmetic industry (Vilpoux \& Cereda, 1995). This plant is cultivated from North to South of Brazil, being the State of Paraná the second largest producer, with a planted area of 154130 hectares and a production of 3780075 tons, lower only to the State of Pará [Brazilian Institute of Geography and Statistics (IBGE), 2019].

The cassava plant is prey to attacks from a large number of arthropod pests, which can cause damage to every part of the plant, causing losses in productivity (Bellotti et al., 1999, 2012). The flies from the Lonchaeidae family contain species which can cause loss to many crops with an agricultural importance (Strikis \& Prado, 2005), among them, the Neosilba perezi (Romero \& Ruppel, 1973), which is associated with the cassava plant (Gisloti \& Prado, 2013) and occurs in the major productive regions of Brazil (De Lorenzi \& Nora, 2016; Gisloti \& Prado, 2011; Lonchaeidae Online, 2015). Females of $N$. perezi lay eggs between the bud`s leaves, the larvae hatch in about four days, perforate the not yet expanded leaves, causing the death of the apical bud (Hogue, 1993; Farias et al., 2007). The attacked plants lose apical dominance and emit new lateral shoots, resulting in delayed 
plant development (Gisloti \& Prado, 2013; De Lorenzi \& Nora, 2016). The highest losses are observed when young plants are attacked, which compromises the quality of the propagation material for future plantings (Otsubo \& Lorenzi, 2004).

Commonly, cassava is propagated trough cuts from the mother plant's stem, known as stem cuttings. For propagation, stem cuttings with a minimum diameter of $20 \mathrm{~mm}$ are selected, because of the amount of nutritive reserves within them (Câmara \& Godoy, 1998; Figueiredo et al., 2014). The damage caused by shoot fly in cassava crop seems to be restricted to stem cuttings production, without significantly affecting root production [International Center for Tropical Agriculture (CIAT), 1981; Bellotti et al., 2002]. However, negative effects on root production are reported by other studies (CIAT 1977; Bellotti et al., 2002). Information on the economic losses caused by $N$. perezi are scarce. Therefore, studies are needed to evaluate the damage caused by the shoot-fly over root productivity, flour production and other characteristics of agronomic and industrial interest, to subsidize further studies on the levels of economic damage and its control.

These measures could be a starting point for planning an integrated pest management aimed at maintaining populations below the level of economic damage. The objective of this work was to determine the potential damage of $N$. perezi, simulated through induced meristem damage, on stem cuttings number, root yield and flour yield in field conditions.

\section{Method}

The experiment was conducted during the period of August 2015 to August 2017, at the Experimental Station of the Instituto Agronômico do Paraná (IAPAR) located in the municipality of Cambará, State of Paraná, Brazil $\left(23^{\circ} 00^{\prime} 26^{\prime \prime} \mathrm{S}, 50^{\circ} 01^{\prime} 55^{\prime \prime} \mathrm{W}\right.$ and $450 \mathrm{~m}$ altitude). The climate of the region is type Cfa, with dry season in the winter, according to the classification of Köppen (Caviglione et al., 2000). During the study period, the lowest rainfall $(<50 \mathrm{~mm})$ occurred in July, while the highest rainfall occurred in January $(\approx 330 \mathrm{~mm})$. The maximum and minimum monthly temperatures varied between $34-36{ }^{\circ} \mathrm{C}$ and $9-20{ }^{\circ} \mathrm{C}$, respectively (Figure 1). The soil of the experimental area is characterized as Tipical Hapludox, and a chemical analysis was performed at a $0-20 \mathrm{~cm}$ depth (Table 1). No liming or fertilization were performed in the experiment.

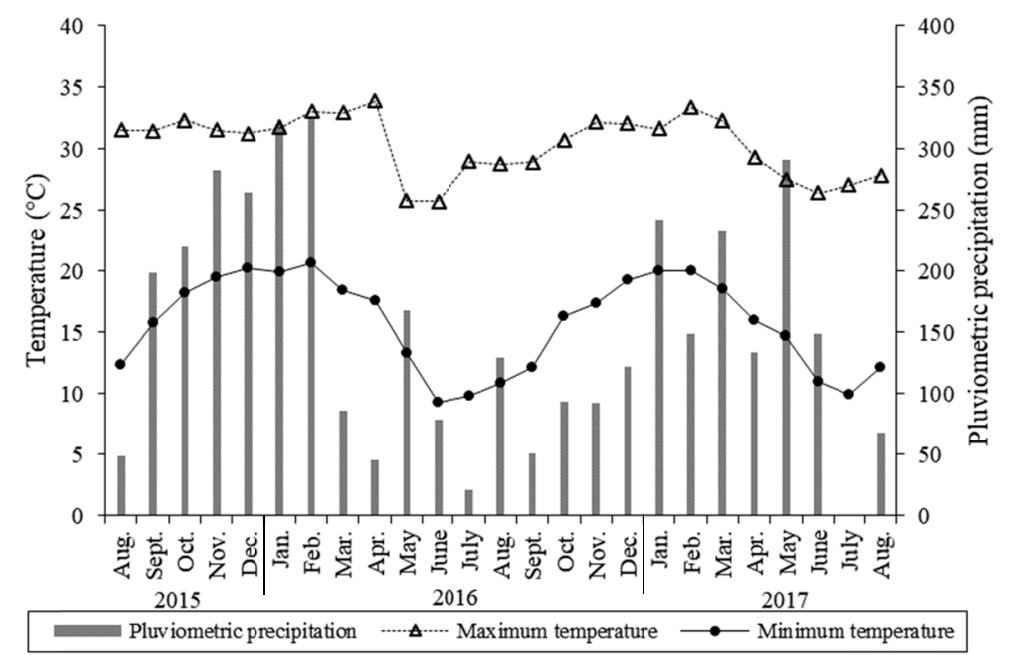

Figure 1. Average maximum and minimal mensal temperatures and accumulated mensal precipitations during the period of August 2015 to August 2017, in Cambará, State of Paraná, Brazil

Table 1. Chemical analyses' results of the soil at a depth of $0-20 \mathrm{~cm}$, during the period of August 2015, in Cambará, State of Paraná, Brazil.

\begin{tabular}{|c|c|c|c|c|c|c|c|}
\hline $\mathrm{P}$ & $\mathrm{C}$ & $\mathrm{pH}$ & $\mathrm{Al}$ & $\mathrm{H}+\mathrm{Al}$ & $\mathrm{Ca}$ & $\mathrm{Mg}$ & $\mathrm{K}$ \\
\hline $\mathrm{mg} \mathrm{dm}^{-3}$ & $\mathrm{~g} \mathrm{dm}^{-3}$ & & $-\cdots$ & ------. & $\operatorname{nol}_{\mathrm{c}} \mathrm{d}$ & ----- & ----------- \\
\hline 49.9 & 17.92 & 4.80 & 0.10 & 7.20 & 4.87 & 1.31 & 0.78 \\
\hline
\end{tabular}




\subsection{Experiment Conduction}

In August of 2015, the experimental area was plowed, meshed and mechanically furrowed. Afterwards, stem cuttings with a 2 to $3 \mathrm{~cm}$ in diameter and $20 \mathrm{~cm}$ in length were planted manually in the horizontal position, with a straight cut at both ends and containing on average five buds. The cultivar used was Santa Helena, registration no. 30002 on 11/25/2013 in the Registro Nacional de Cultivares do Ministério da Agricultura e Pecuária e Abastecimento (RNC/MAPA).

During the course of the study pest and disease control was not necessary. The control of weeds was done by manual weeding in the following periods: soon after the emergence of shoots from the stem cuttings, one year after planting (period when stem cuttings were collected) and before harvesting the roots.

The experimental design was a randomized block with three repetitions in a factorial scheme with an additional treatment $(10 \times 4+1)$. The first factor was 10 levels of forced apical stem removal $(10,20,30,40,50,60,70,80$, 90 and $100 \%$ ) which corresponds to the percentage of plants in the plot with the apical meristem removed. The second factor refers to the number of cuts (simulation of a re-infestation of $N$. perezi) over an annual cycle. The first cut was performed at 45 days after emergence (DAE), and subsequent cuts ranged from 49 to 73 days (Table 2). The additional treatment corresponds to control treatment, without any damage.

Table 2. Crop year, number of cuts (simulation of re-infestations of $N$. perezi) and days after emergence (DAE) of the plants in which the cuts were made, as well as the harvesting of stem cuttings or roots. Cambará, State of Paraná, yield years of 2015 to 2017

\begin{tabular}{lll}
\hline Crop year & No. of cuts & DAE in which the cuts were made \\
\hline \multirow{3}{*}{$2015 / 2016$} & 1 & 45 \\
& 2 & 45 and 109 \\
& 3 & 45,109 and 178 \\
& 4 & $45,109,178$ and 251 \\
& Stem cuttings harvest ${ }^{1}$ & 289 \\
$2016 / 2017$ & 1 & 424 \\
& 2 & 424 and 473 \\
& 3 & 424,473 and 523 \\
& 4 & $424,473,523$ and 589 \\
\hline
\end{tabular}

Note. ${ }^{1}$ Accumulated damage from only one year; ${ }^{2}$ Accumulated damage from 2 years.

Each experimental plot was composed of six rows with 12 plants each, being considered a useful plot the four central rows, disregarding the first and last plant (10 useful plants in the line). Plant spacing was $0.9 \mathrm{~m}$ between rows and $0.8 \mathrm{~m}$ between plants. Each plot containing the combination of level forced damage and the number of cuts was subdivided into two (two rows with 10 plants each), so that for the variables related to the root harvest, half of the plot was cut for damage simulation only for the first year and the other half for the accumulated two consecutive years.

The number of stem cuttings per plant was determined at 289 days after emergence by cutting the shoots from the plants in segments of $20 \mathrm{~cm}$, counting the total number of stem cuttings with a diameter greater than $20 \mathrm{~mm}$ (M20) and greater than $25 \mathrm{~mm}$ (M25), which are the diameters recommended by Câmara and Godoy (1998) for the cultivation of cassava, because they present a higher velocity and percentage of emergence of shoots. The cuts were performed starting at $20 \mathrm{~cm}$ above ground level.

In July 2017, the plots were harvested. One week before the harvest of the roots, the plant's shoot system was removed. During the harvest, the soil was de-compacted using a cassava sub-soiler. The evaluated characteristics were: root yield (RY) and flour yield (FY).

The yield of the cassava roots, expressed as $\mathrm{tha}^{-1}$, was obtained by weighing the roots of all the plants harvested inside of the plot area. The flour yield (FY) was obtained by the hydrostatic scale method using the following equation:

$$
\mathrm{Y}=2.57567+0.0752613 \mathrm{X}
$$

Where, $\mathrm{Y}=$ flour percentage; $\mathrm{X}=$ weight of $3 \mathrm{~kg}$ of roots in a hydrostatic scale (Fukuda \& Caldas, 1987). 


\subsection{Statistical Analysis}

The data were submitted to an analysis of variance to verify the significance of the variables evaluated in relation to the level of damage. Subsequently, regression analyzes were performed to determine the curve model and the determination coefficient $\left(\mathrm{R}^{2}\right)$. The statistical analyzes were performed using the $\mathrm{R}$ software (R Development Core Team, 2012) and the ExpDes package (Ferreira et al., 2011).

\section{Results and Discussion}

For the number of stem cuts produced (M20 and M25), root yield (RY) and flour yield (FY), the variance coefficient was less than $10 \%$, demonstrating high experimental precision. The variance analysis' $\mathrm{F}$ test resulted in a significant effect towards the blocks $(\mathrm{P}<0.05)$ for each of the evaluated characteristics, demonstrating the existence of heterogeneity in the experimental area and that the randomized block design was appropriately used in this study (Table 3 ).

The effect between the number of stem cuts and the interaction induced damage $\times$ stem cuts, showed no significance for M20 and M25 ( $\mathrm{P} \geq 0.05)$. However, the induced damage level was significant $(\mathrm{P}=0.02)$ for M20, indicating that the number of stem cuttings produced with a diameter greater than $20 \mathrm{~mm}$ were affected by the damage level induced to the plant's apical meristem. There was no significance for stem cuttings produced with a diameter greater than $25 \mathrm{~mm}$ (Table 3 ).

Table 3. Variance analysis on stem cuttings with a diameter greater than $20 \mathrm{~mm}$ (M20) and $25 \mathrm{~mm}$ (M25), root yield in t ha ${ }^{-1}$ (RY) and flour yield in $\mathrm{t} \mathrm{ha}^{-1}$ (FY). Cambará, State of Paraná, during 2015 to 2017.

\begin{tabular}{|c|c|c|c|c|c|c|c|c|c|c|c|c|c|}
\hline \multirow{3}{*}{ Source of variation } & \multirow{3}{*}{ GL } & \multicolumn{12}{|c|}{$\mathrm{MS}^{1}$} \\
\hline & & \multicolumn{4}{|c|}{1 year accumulated } & \multicolumn{4}{|c|}{1 year accumulated } & \multicolumn{4}{|c|}{2 years accumulated } \\
\hline & & M20 & & M25 & & RY & & FY & & $\mathrm{RY}$ & & FY & \\
\hline Block & 2 & 47461 & $* *$ & 18630 & $* *$ & 332.5 & $* *$ & 30.5 & $*$ & 536.6 & $* *$ & 21.5 & $* *$ \\
\hline Induced damage level & 10 & 2853 & $*$ & 1501 & ns & 27.4 & ns & 4.3 & ns & 109.6 & ns & 1.9 & ns \\
\hline $\mathrm{N}^{\mathrm{o}}$ of cuts & 3 & 957 & ns & 1351 & ns & 19.0 & ns & 13.8 & ns & 11.5 & ns & 2.2 & ns \\
\hline Damage x Cuts & 30 & 480 & ns & 425 & ns & 26.3 & ns & 5.2 & ns & 58.5 & ns & 2.4 & ns \\
\hline Additional vs Factorial & 1 & 216 & ns & 38 & ns & -1120.5 & $* *$ & -231 & $* *$ & -2875.5 & $* *$ & -96.5 & $* *$ \\
\hline Residue & 88 & 1243 & & 869 & & 53.1 & & 9.6 & & 74.4 & & 3.2 & \\
\hline Total & 134 & & & & & & & & & & & & \\
\hline $\operatorname{CV}(\%)^{2}$ & & 0.69 & & 2.63 & & 5.92 & & 9.61 & & 5.80 & & 9.46 & \\
\hline
\end{tabular}

Note. ${ }^{\mathrm{ns}}$ not significant, ${ }^{* *}$ and $*$ significant at $1 \%(\mathrm{P}<0.01)$ and $5 \%(\mathrm{P}<0.05)$ of probability according $\mathrm{F}$ test, respectively.

${ }^{1} \mathrm{MS}$ : mean square; ${ }^{2} \mathrm{CV}$ : coefficient of variation.

The production of stem cuttings larger than $20 \mathrm{~mm}$ in diameter decreased linearly with increasing levels of damage to the apical meristem $(y=-0.0117 x+5.7298 ; P \leq 0.05)$ at a coefficient of determination of $R^{2}=0.8153$ (Figure 2). In general, plants produce a greater number of branch ramifications when the apical meristem is damaged, resulting in the induction of lateral shoots which compete for photo-assimilates and reduce the stems' diameter. The induced damage levels showed that the number of M20 was 5.7 stem cuttings in plants with 10\% damage, and 4.3 when the damage was $100 \%$, which would result in an estimated loss of 19,444 stem cuttings (cuttings with a $20 \mathrm{~cm}$ long and $20 \mathrm{~mm}$ in diameter size) per hectare. This decrease in stem production is similar to that found by CIAT (1981) and Bellotti et al. (1999), but in contrast with that found by Farias et al. (2007), however, these differences in results may be due to the stem diameter considered, since if branches with a diameter greater than $25 \mathrm{~mm}$ were considered, no difference would be found in this study.

In favorable cassava cultivating conditions, one hectare with a 12-month duration, generates stem cuttings enough for a 4 to 5 -hectare replantation of cassava (Fialho \& Vieira, 2013), thus, stems obtained from a $20 \%$ to $25 \%$ of the initial cultivation area, are enough to initiate a new cultivation. The cost of stem cutting acquisition for a hectare of cultivation, is about 7 to $8 \%$ of the total cost of the plant's cultivation (Furlaneto et al., 2007). The most severe $N$. perezi damage simulation level reduce the amount of stem cuttings produced for a new plantation, which can result in a higher labor and consequently a higher total implementation cost. 


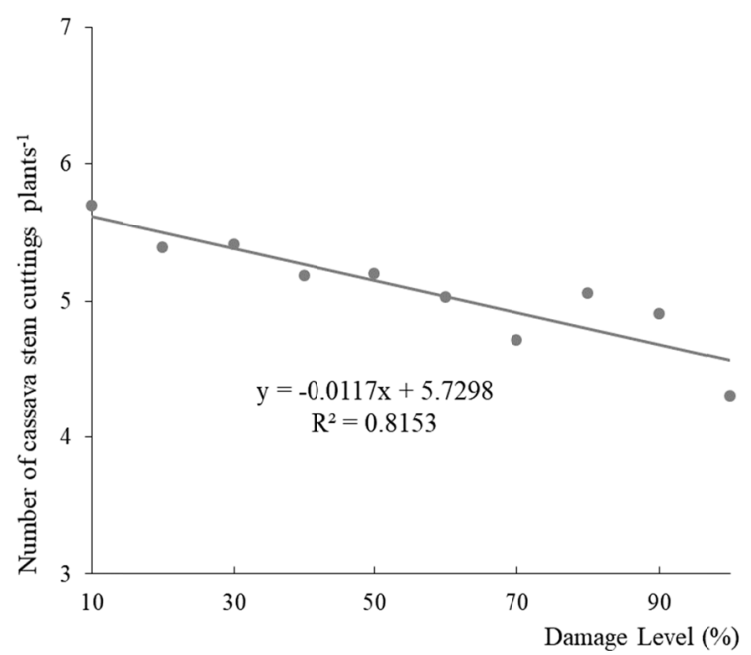

Figure 2. Number of stem cuttings produced with a diameter greater than $20 \mathrm{~mm}(\mathrm{~A})$ in relation to the induced damage level to the plant's apical meristem. Cambará, State of Paraná, Brazil

The effects of the induced damage levels, number of cuts and the interaction between damage $\mathrm{x}$ cut were not significant $(\mathrm{P} \geq 0.05)$ for the RY and FY characteristics, for the one and two accumulated years, indicating that the damage caused to the shoot system section of the plant did not result in losses towards root and flour production (Table 3). This result corroborates studies conducted by CIAT (1977), Bellotti et al. (2002) and Farias et al. (2007), where the shoot-fly attack did not affect the root yield and starch content of the studied varieties.

Moreira et al (2014) verified yield decrease in the Caitité and Sergipe cassava varieties submitted to five pruning intervals $(0,2,4,6$ and 8 months), however, for dry mass content, starch content, flour yield and starch production in roots, there was no difference between plants with pruning intervals and non-pruned plants in each variety. The authors attribute such occurrence to the fast recovery of the plant's shoot system and the increase of leaf area on the pruned plants. These results show the plasticity of the cassava and the rusticity of the plant towards damage caused to its shoot system.

Root and flour yield were not affected by the damage induced to the apical meristem. The average root yield observed was $45.8 \mathrm{t} \mathrm{ha}^{-1}$ and $44.7 \mathrm{tha}^{-1}$ and the average flour yield was $12.9 \mathrm{t} \mathrm{ha}^{-1}$ and $12.3 \mathrm{t} \mathrm{ha}^{-1}$ for one and two years of accumulated damage, respectively (Figures 3 and 4). Different from the present study, Rós et al. (2011) found that single-stem cultivars had their root yields impaired as a result of meristem damage. The probable cause for this difference must be related to the cassava cultivars used in this study, which have higher stems and branches yield. Thus, future studies involving varieties with different branching habits could be studied to elucidate this matter.

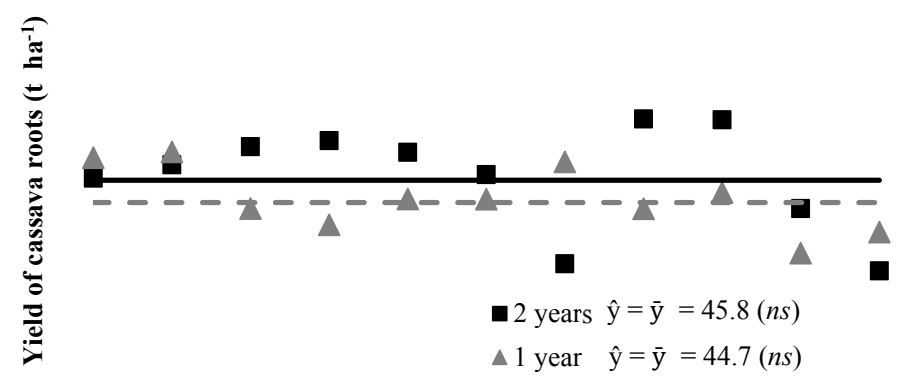

Damage level (\%)

Figure 3. Cassava root yield $\left(\mathrm{t} \mathrm{ha}^{-1}\right)$ in ten induced damage levels on the plant's apical meristem. Cambará, State of Paraná, Brazil, during 2015 to 2017 


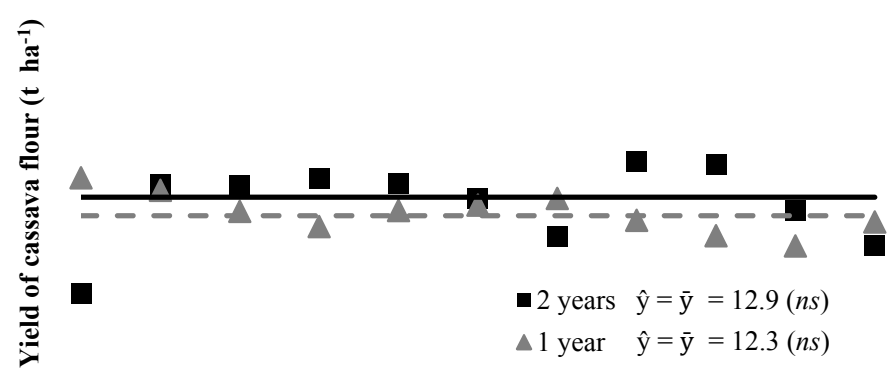

Damage level (\%)

Figure 4. Cassava flour yield $\left(\mathrm{t} \mathrm{ha}^{-1}\right)$ in ten induced damage levels on the plant’s apical meristem. Cambará, State of Paraná, Brazil, during 2015 to 2017

The induced meristem damage does not affect root and flour yield for the Santa Helena cultivar, indicating that $N$. perezi has no potential to cause damage towards these characteristics.

The induced meristem damage decreases the amount of stem cuttings with ideal conditions for cassava cultivating, indicating that $N$. perezi has potential damage towards the production of stem cuttings.

\section{References}

Aidar, S. T., Morgante, C. V., Chaves, A. R. M., Costa Neto, B. P., Vitor, A. B., Martins, D. R. P. S., ... Oliveira, E. J. (2015). Características fisiológicas, produção total de raízes e de parte aérea em acessos de Manihot esculenta em condições de déficit hídrico. Revista Brasileira de Geografia Física, 8(7), 685-696. https://doi.org/10.5935/1984-2295.20150024

Bellotti, A. C., Arias, B. V., Vargas, O. H., Reyes, J. A. Q., \& Guerrero, J. M. (2002). Insectos y acaros dañinos a la yuca y su control. In B. Ospina \& H. Ceballos (Eds.), La yuca en el tercer milenio: Sistemas modernos de producción, procesamiento, utilización y comercialización. Cali: CIAT/CLAYUCA.

Bellotti, A. C., Herrera-Campo, B. V., \& Hyman, G. (2012). Cassava production and pest management: Present and potential threats in a changing environment. Tropical Plant Biology, 5(1), 39-72. https://doi.org/ 10.1007/s12042-011-9091-4

Bellotti, A. C., Smith, L., \& Lapointe, S. L. (1999). Recent advances in cassava pest management. Annual Review of Entomology, 44(1), 343-370. https://doi.org/10.1146/annurev.ento.44.1.343

Câmara, G. M. S., \& Godoy, O. P. (1998). Desempenho vegetativo e produtivo de cultivares de mandioca (Manihot esculenta Crantz) a partir de manivas com diferentes diâmetros. Scientia Agricola, 55(2), 326-331. https://doi.org/10.1590/S0103-90161998000200024

Caviglione, J. H., Kiihl, L. R. B., Caramori, P. H., Oliveira, D., Galdino, J., Borrozino, E., \& Pugsley, L. (2012). Cartas climáticas do Estado do Paraná. Londrina: IAPAR.

CIAT (Centro Internacional de Agricultura Tropical). (1977). Informe Anual: Cassava production systems. Cali: CIAT.

CIAT (Centro Internacional de Agricultura Tropical). (1981). Informe anual: Programa de yuca. Cali: CIAT.

De Lorenzi, E. F. P., \& Nora, I. (2016). Danos e manejo da mosca-do-broto da mandioca. Agropecuária Catarinense, 29(3), 38-41.

El-Sharkawy, M. A. (2003). Cassava biology and physiology. Plant Molecular Biology, 53(5), 621-641. https://doi.org/10.1023/B:PLAN.0000019109.01740.c6

FAO (Food and Agriculture Organization of the United Nations). (2019a). Save and Grow: Cassava. Retrieved May 20, 2019, from http://www.fao.org/ag/save-and-Grow/cassava/en/1/index.html

FAO (Food and Agriculture Organization of the United Nations). (2019b). FAOSTAT. Retrieved April 20, 2019, from http://www.fao.org/faostat/en/\#data/QC/visualize

Farias, A. R. N., Ferreira Filho, J. R., \& Mattos, P. L. P. (2007). Mosca-do-broto-e efeito do ataque em cultivares de mandioca. Retrieved from http://www.infobibos.com/Artigos/2007_4/mandioca/index.htm 
Ferreira, E. B., Cavalcanti, P. P., \& Nogueira, D. A. (2011). Experimental designs: Um pacote R para análise de experimentos. Revista da Estatística da Universidade Federal de Ouro Preto, 1(1), 1-9.

Fialho, J. F., \& Vieira, E. A. (2013). Manejo e tratos culturais da mandioca. Mandioca no Cerrado: Orientações Técnicas, 2, 61-88.

Figueiredo, P. G., Bicudo, S. J., Moraes-Dallaqua, M. A., Tanamati, F. Y., \& Aguiar, E. B. (2014). Componentes de produção e morfologia de raízes de mandioca sob diferentes preparos do solo. Bragantia, 73(4), 357-364. https://doi.org/10.1590/1678-4499.0150

Fukuda, W. M., \& Caldas, R. C. (1987). Relação entre os conteúdos de amido e farinha em mandioca. Revista Brasileira de Mandioca, 6(2), 57-63.

Furlaneto, F. D. P. B., Kanthack, R. A. D., \& Esperancini, M. S. T. (2007). Análise econômica da cultura da mandioca no Médio Paranapanema, Estado de São Paulo. Informações Econômicas, 37(10), 20-26.

Gisloti, L. J., \& Prado, A. P. (2011). Cassava Shoot Infestation by larvae of Neosilba perezi (Romero \& Ruppell) (Diptera: Lonchaeidae) in São Paulo State, Brazil. Neotropical Entomology, 40(3), 312-315. https:/doi.org/ $10.1590 /$ S1519-566X2011000300004

Gisloti, L. J., \& Prado, A. P. (2013). Aspectos da biologia e morfologia de machos da mosca-dos-brotos (Diptera: Lonchaeidae). Arquivos do Instituto Biológico, 80(4), 416-423. https://doi.org/10.1590/S1808-16572013 000400007

Hogue, C. L. (1993) Latin American insects and entomology. Berkeley: University California Press.

IBGE (Instituto Brasileiro de Geografia e Estatística). (2019). Cidades. Produção Agrícola Municipal (Lavoura Temporária 2015). Mandioca, Área plantada, Comparação entre municípios do Paraná. Retrieved June 22, 2017, from http://www.http://www.cidades.ibge.gov.br/comparamun/compara.php?lang=\&lista=uf\&coduf= 41\&idtema $=158 \& \operatorname{codv}=\mathrm{V} 108$

Lonchaeidae Online. (2015). Retrieved from http://lonchaeidae.myspecies.info/category/lonchaeidade/lonchaein ae/neosilba/neosilba-perez

Moreira, G. L. P., Viana, A. E. S., Cardoso, A. D., da Silva Santos, V., Matsumoto, S. N., \& Andrade, A. C. B. (2014). Intervalos entre podas de duas variedades de mandioca. Bioscience Journal, 30(6), 1757-1767. Retrieved from http://www.seer.ufu.br/index.php/biosciencejournal/article/view/22211

Otsubo, A. A., \& Lorenzi, J. O. (2004). Cultivo da mandioca na região Centro-Sul do Brasil. Embrapa Agropecuária Oeste-Sistema de Produção (INFOTECA-E).

R Core Team. (2012). R: A language and environment for statistical computing. Vienna: R Foundation for Statistical Computing. Retrieved from http://www.R-project.org

Rós, A. B., Hirata, A. C. S., De Araújo, H. U., \& Narita, N. (2011). Crescimento, fenologia e produtividade de cultivares de mandioca. Pesquisa Agropecuária Tropical, 41(4), 552-558. https://doi.org/10.5216/ pat.v41i4.11075

Strikis P. C., \& Prado, A. P. (2005). A new species of the genus Neosilba (Diptera: Lonchaeidae). Zootaxa, 828(1), 1-14. https://doi.org/10.11646/zootaxa.828.1.1

Vilpoux, O., \& Cereda, M. P. (1995). Caracterização das fecularias no Brasil. Botucatu: Centro de Raízes Tropicais, UNESP.

\section{Copyrights}

Copyright for this article is retained by the author(s), with first publication rights granted to the journal.

This is an open-access article distributed under the terms and conditions of the Creative Commons Attribution license (http://creativecommons.org/licenses/by/4.0/). 